\title{
O USO DE DRONES NA PRESERVAÇÃO DE RESERVAS
} AMBIENTAIS

\section{THE USE OF DRONES IN PRESERVATION OF ENVIRONMENTAL RESERVES}

MARIA GABRIELA VAZ OLIVEIRA

Acadêmica do curso de Direito - Escola de Direito Dom Helder Câmara - Belo Horizonte - Mg. E-mail: Divigabi2010@hotmail.com.br

CAIO AUGUSTO SOUZA LARA Mestre e Doutor em Direito pela Faculdade de Direito da Universidade Federal de Minas Gerais - UFMG. Professor da Escola Superior Dom Helder Câmara. Pesquisador associado ao Programa RECAJ-UFMG - Acesso à Justiça e Solução de Conflitos. Secretário de Comunicação do Conselho Nacional de Pesquisa e Pósgraduação em Direito - CONPEDI. Belo Horizonte MG. Email:caiolarabh@yahoo.com.br

\section{RESUMO}

O direito ambiental é entendido como um sistema jurídico de normas que visam a proteção do meio ambiente. Nesse cenário, a otimização dos direitos ambientais passa a ser a grande preocupação debatida no final século $X X$ até os tempos atuais. Com a realização da declaração de Estocolmo (1972), são estabelecidos critérios e princípios que norteiam os países, visando incentivar a preservação do meio ambiente. No Brasil, o direito ambiental só foi tratado na constituição de 1988, presente no capitulo VI, artigo 225, com a seguinte literalidade: "Todos têm direito ao meio ambiente ecologicamente equilibrado, bem de uso comum 
Personalidade Acadêmica Homenageada:

Raymundo Juliano Feitosa (Universidade Federal do Rio Grande do Norte - UFRN)

do povo e essencial à sadia qualidade de vida, impondo-se ao Poder Público e à coletividade o dever de defendê-lo e preservá-lo para as presentes e futuras gerações" (BRASIL, 1988). Fica evidente a obrigação do Poder Público e da coletividade defender e preservar o meio ambiente. Desse modo, todas as atividades que visam esses objetivos são amparadas pelo texto legal, incluindo, portanto, as aeronaves não tripuladas, popularmente conhecidas como drones, estas que possibilitam de maneira mais eficiente a monitoração e a fiscalização do espaço, mais especificamente, da área indígena, uma vez que no local se encontram os maiores números de violações territoriais para a exploração ilegal. Possuindo a capacidade de coletar dados e imagens de alta resolução, a implantação do drone é ideal para proporcionar uma visão do alto de forma fácil e ágil e o seu sobrevoo fornece uma visão de localidades distantes e de difícil acesso. Essas máquinas já estão sendo usadas em combates contra incêndio, em resgastes decorrentes de desastres em áreas remotas que precisam de localização de vítimas de maneira rápida, monitoramento de espécies de animais ameaçadas de extinção, dentre outras funções. Uma alternativa para que a implantação de drones se dê de maneira não partidária, é a utilização dessas aeronaves pelos próprios indivíduos que possuem um interesse mais próximo de preservar o meio ambiente, qual sejam, os indígenas, estes que são afetados diretamente com a violação das demarcações de suas terras pelas grandes madeireiras ou empresas pecuárias. Um exemplo de que essa tecnologia está dando certo quando utilizada pelos mais interessados nesse objetivo é a comunidade Wapinchana, na Guiana, que aprenderam a usar os drones para se protegerem de ameaças de desmatamento, mineração e assassinatos. Por conseguinte, a hipótese levantada dessa pesquisa se coloca como: A tecnologia pode ser empregada de forma eficaz para o auxílio da fiscalização e da preservação ambiental? O emprego de tecnologia para a fiscalização no Brasil ainda é minimalista ou é de emprego autônomo de pequenos órgãos públicos. A metodologia utilizada é a jurídica-sociológica, com o tipo de investigação foi empregado na classificação de Witker (1985) e Gustin (2010), o tipo jurídico-projetivo. Observa-se, o objetivo dessa pesquisa de avaliar a legislação e os impactos da tecnologia em benefício e em prejuízo do meio ambiente, partindo do aumento de áreas de preservação que foram violadas e analisando os meios 
Personalidade Acadêmica Homenageada:

Raymundo Juliano Feitosa (Universidade Federal do Rio Grande do Norte - UFRN)

eficazes para a preservação e fiscalização de áreas que deveriam ser preservadas. A partir do que foi retratado, é de suma importância ressaltar a necessidade da tecnologia. Essa apesar de poder contribuir para a degradação ambiental, é capaz de reverter essa situação, desde que se utilizada com consciência. É importante perceber que no Brasil existe regulamentação para os crimes ambientais, para os drones e para a proteção do ecossistema como um todo, fazendo com que o problema no país não seja legislativo, mas sim execução das legislações aplicáveis.

PALAVRAS-CHAVE: Preservação; Ambiente; Drones; Direito.

\section{REFERÊNCIAS}

BRASIL. Constituição da República Federativa do. Congresso Nacional, Brasília, 1988.

Brasília, 1998.

Lei $\mathrm{n}^{\circ}$ 9.605/98 - Lei de Crimes Ambientais. Congresso Nacional :

FONTES, Juliana Carvalho; POZZETTI, Valmir César. O Uso dos Veículos não Tripulados no Monitoramento Ambiental na Amazônia. Revista de Direito e Sustentabilidade, Curitiba, v. 2, p.149-164, 01 dez. 2016.

GUSTIN, Miracy Barbosa de Sousa; DIAS, Maria Tereza Fonseca. (Re)pensando a pesquisa jurídica: teoria e prática. ${ }^{3}$. ed. Belo Horizonte: Del Rey, 2010

SAMPAIO, José Adércio Leite; MASCARENHAS, Carolina Miranda do Prado. O direito fundamental ao meio ambiente ecologicamente equilibrado necessita de um estado ambiental? Revista Brasileira de Direitos e Garantias Fundamentais, Curitiba, v. 2, p.40-57, jul./dez. 2016.

SAMPAIO, José Adércio Leite; PINTO, João Batista Moreira. Esverdeamento do constitucionalismo democrático e os direitos humanos: desafios e construções comuns. Veredas do Direito, Belo Horizonte, v. 13, p.81-114, Maio/Agosto 2016.

SILVA, M. A. ; SELLOS-KNOERR, Viviane Coelho de . Responsabilidade social da empresa e subcidadania pautas para uma reflexão de índole constitucional. Revista Jurídica- Unicuritiba, v. 2, p. 435-453, 2013. 
Personalidade Acadêmica Homenageada:

Raymundo Juliano Feitosa (Universidade Federal do Rio Grande do Norte - UFRN)

WITKER, Jorge. Como elaborar una tesis en derecho: pautas metodológicas y técnicas para el estudiante o investigador del derecho. Madrid: Civitas, 1985. 